\title{
深度贫困地区乡村地域系统演化研究 一河北省阳原县为例
}

\author{
李玉恒 $1,2,3$, 宋传圭 $1,2,3$, 阎佳玉 ${ }^{1,2,3}$, 黄惠倩 $1,2,3$ \\ (1. 中国科学院地理科学与资源研究所, 北京 100101；2. 中国科学院区域可持续发展分析与模拟重点实验室, 北京 100101; \\ 3. 中国科学院大学资源与环境学院, 北京 100049)
}

\begin{abstract}
摘 要: 在中国快速城镇化与工业化影响下,广大乡村地区尤其是深度贫困地区面临的“乡村病”问题凸显,影响到 乡村可持续发展进程, 函需重视乡村振兴。科学把握乡村地域系统的演化过程与格局特征, 提出乡村振兴的方向 与适宜路径, 对促进乡村可持续发展具有重要意义。论文以河北省阳原县为例, 从土地利用变化视角探究了深度 贫困地区乡村中心集聚性与成长性, 揭示了乡村地域系统的演化过程与格局。研究发现: (1) 伴随着耕地面积的不 断减少, 乡村建设用地扩张强度明显高于乡镇政府驻地与县城地区的建设用地扩张强度; (2) 生产要素在城、镇、村 间不均衡集聚的特征明显,导致县城邻近地区、乡镇政府所在地、偏远乡村地区的中心集聚性依次降低; (3) 受区 位、交通、自然环境等因素的影响,县城邻近地区、区位较好的乡镇以及交通干线附近地区更易于集聚生产要素,成 为乡村成长性的高值区; (4) 深度贫困地区乡村常住人口持续减少, “人减地增”的乡村空心化问题严峻。文章强调 应大力发展县域经济, 强化城乡联系, 提升县城对乡村的辐射带动作用, 并积极推进村镇化发展, 开展空心村土地 综合整治,培育乡村社会资本, 激发乡村发展的内生动力。
\end{abstract}

关 键 词:乡村衰退; 乡村演化; 可持续发展;村镇化;河北

人地关系地域系统是地理学的研究核心 ${ }^{[1]}$ 。乡 村是由自然、社会、经济、文化等多方面要素相互 联系、相互作用下构成的动态、开放、复杂的地域 系统 ${ }^{[2]}$ 。在乡村内核系统与外部发展主导过程如全 球化、工业化等交互作用下,乡村系统的结构与功 能不断发生演化与分异 ${ }^{[3-5]}$ 。改革开放以来, 伴随着 中国快速的城镇化与工业化进程, 广大乡村地区尤 其是地处偏远、交通不便的乡村地区普遍患上了 “乡村病”, 主要表现为农村生产要素快速非农化、 社会主体老弱化、农村土地空废化、水土环境污损 化以及深度贫困化。“乡村病”问题严重制约了中国 可持续发展进程, 亟需得到关注 ${ }^{[6-7]}$ 。

中国现有 14 个集中连片贫困地区,其中深度贫 困地区受资源禀赋不优、地理区位偏远、基础设施
与公共服务不强等因素影响, “乡村病”问题尤为凸 出, 青壮年劳动力大量流失、农业经营主体老弱化、 土地荒废及低效利用等问题较为普遍, 导致了乡村 经济调粉, 进而加剧了人口流失与贫困化, 乡村发 展面临全面衰退境地 ${ }^{[8-9]}$, 亟需补齐深度贫困地区乡 村发展短板。

当前, 中国正全力实施乡村振兴战略, 通过构 建平等、协调、互补的城乡关系, 着力推进乡村地区 的全面发展, 具有重要的现实意义 ${ }^{[10]}$ 。基于此, 针 对深度贫困地区的乡村振兴, 应着眼于揭示深度贫 困地区乡村地域系统的演化过程与特征, 厘清城、 镇、村演化态势,甄别制约乡村发展的短板因素, 从 而提出乡村振兴的适宜路径与措施。

土地是乡村发展的重要生产要素,乡村土地利

收稿日期:2020-01-13;修订日期: 2020-04-27。

基金项目: 国家自然科学基金项目(41771191,41931293); 中国科学院地理科学与资源研究所“可桢杰出青年人才基金” (2018RC102)。[Foundation: National Natural Science Foundation of China, No. 41771191 and 41931293; Kezhen Excellent Young Scientist Fund of IGSNRR, CAS, No. 2018RC102. ]

第一作者简介: 李玉恒(1983-), 男, 河北石家庄人,博士, 副研究员, 主要研究方向为乡村地域系统演化、乡村弹性与可持续 发展。E-mail: liyuheng@igsnrr.ac.cn

引用格式: 李玉恒, 宋传圭, 阎佳玉, 等. 深度贫困地区乡村地域系统演化研究: 以河北省阳原县为例 [J]. 地理科学进展, 2020, 39(6): 951-959. [Li Yuheng, Song Chuanyao, Yan Jiayu, et al. Change of rural regional system in deep poverty areas: A case study of Yangyuan County, Hebei Province. Progress in Geography, 2020, 39(6): 951-959. ] DOI: 10.18306/dlkxjz.2020.06.006 
用变化是城乡生产要素空间流动与集聚在乡村地 域引发的地表变化, 也是乡村地域功能演化与经济 社会结构重塑等过程的外在表征 ${ }^{[1-12]}$ 。受制于地形 与区位条件, 深度贫困地区的交通通达性普遍较 差, 经济社会发展水平相对较低, 县域综合实力不 强, 贫困化问题突出, 形成了独特的乡村土地利用 形态。本文以河北省张家口市阳原县为例, 深人分 析深度贫困地区乡村土地利用变化的时空格局及 其作用机制, 以此揭示乡村地域系统演化特征, 为 科学推进深度贫困地区乡村振兴战略提供依据。

\section{1 数据来源与研究方法}

\section{1 研究区域概况}

阳原县(图 1) 位于 $39^{\circ} 53^{\prime} \sim 40^{\circ} 22^{\prime} \mathrm{N} 、 113^{\circ} 54^{\prime} \sim$ $114^{\circ} 48^{\prime} \mathrm{E}$, 隶属于河北省张家口市, 东接张家口市宣 化区, 南连蔚县, 西与山西省大同市毗邻, 北与张家 口市怀安县和大同市天镇县交界, 总面积为 1849 $\mathrm{km}^{2}$ 。阳原县地处黄土高原与内蒙古高原向华北平 原过渡地带, 境内地形地貌复杂多样, 全县平均海 拔 $1100 \mathrm{~m}$, 最低海拔 $759 \mathrm{~m}$, 最高海拔 $2022 \mathrm{~m}$,地势 南北环山, 桑干河由西向东横贯全境, 山地、山前丘 陵、平原等多种地貌类型相间, 其中山区、山麓平
原、河川分别占全县总面积的 $27 \%$ 、57\%和 $16 \%$, 呈 现“两山夹一川”的典型山区地貌。

长期以来, 阳原县经济基础薄弱, 发展落后。 2017 年阳原县地区生产总值 47.13 亿元, 人均 1.87 万元, 不到全国平均水平的 $1 / 3$; 县域产业结构比为 $21: 32: 47$, 第一产业在国民经济中依旧占有较高的 比重。2017 年阳原县城镇化率为 $42.92 \%$, 低于全 国平均水平 15.6 个百分点; 人民生活水平较低, 按 照 2017 年全国贫困标准人均年收人 3335 元计算, 全县贫困发生率高达 $19.93 \%$, 是河北省 10 个深度 贫困县之一。

\section{2 数据来源}

本文利用中国科学院资源环境数据云平台提 供的 $2000 、 2005 、 2010 、 2018$ 年的 $30 \mathrm{~m} \times 30 \mathrm{~m}$ 土地利 用栅格数据, 分析了阳原县城、镇、村建设用地的时 空演变特征。土地利用栅格数据是以各期 Landsat TM/ETM、Landsat 8 遥感影像为主要数据源, 通过 人工目视解译生成, 其中土地利用类型包括耕地、 林地、草地、水域、建设用地和未利用土地 6 个一级 类型以及 25 个二级类型。

\section{3 研究方法}

\subsection{1 格网单元分析}

本文采用格网单元分析方法,刻画乡村建设用

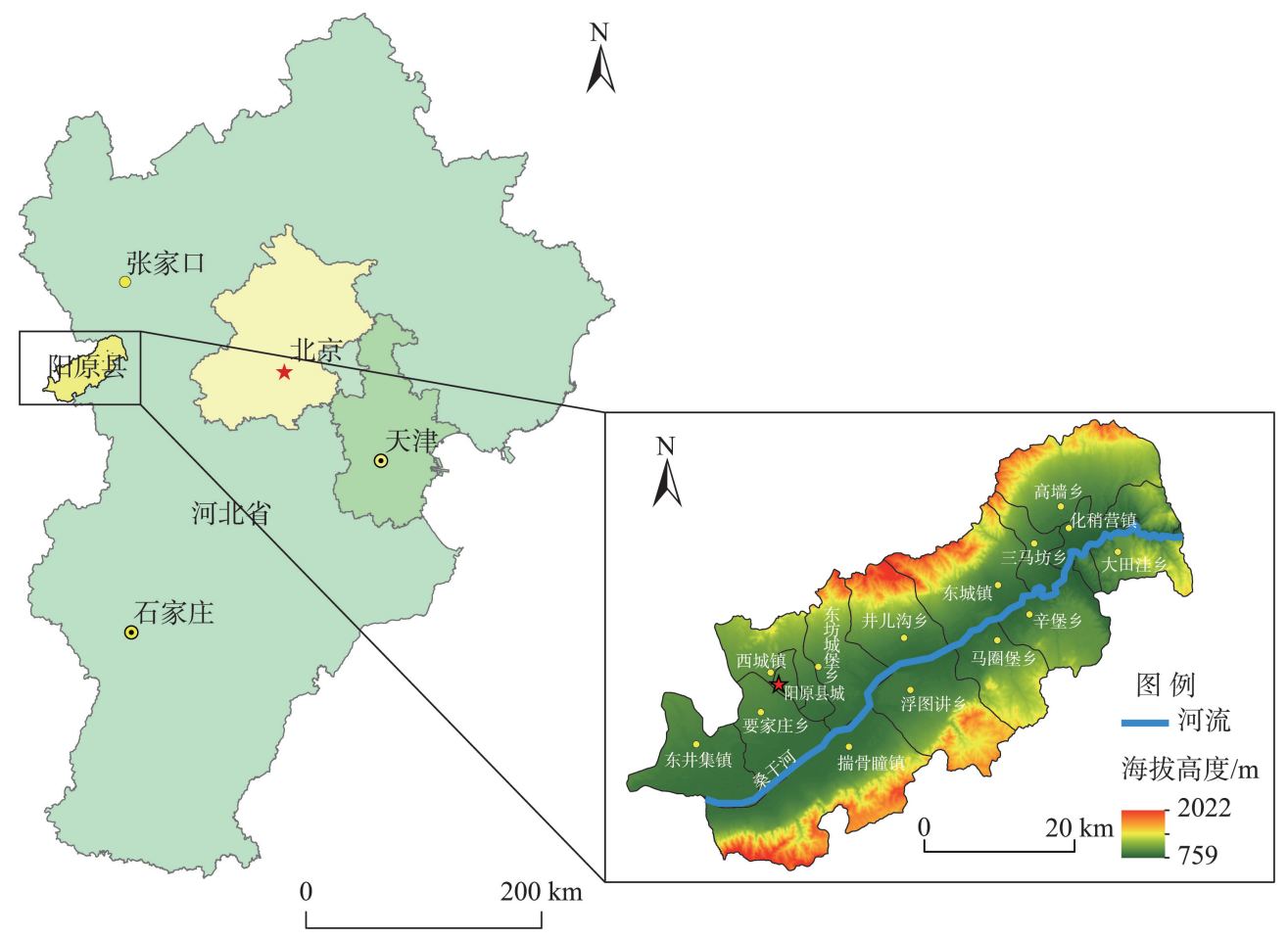

图 1 阳原县区位与地形图

Fig.1 Location and terrain of Yangyuan County 
地空间演化过程。具体方法是利用格网对乡村建 设用地面积以及建设用地变化量进行分区统计, 将 大尺度地块的属性值赋予到小尺度的网格中, 实现 空间降尺度过程, 为进一步探测乡村建设用地的中 心集聚性与空间差异性奠定基础 ${ }^{[3-15]}$ 。

\subsection{2 乡村中心集聚性识别}

乡村中心性是反映乡村建设用地集聚程度的 重要指标, 中心性水平越高代表建设用地越集中, 利用强度越高。本文从土地利用角度出发, 将基本 没有农业用地、完全变为城市建设用地的地区划分 为城市用地, 从而对城市与乡村进行区分, 进而实 现对城市与乡村建设用地的提取。

在提取 $2000 、 2005 、 2010 、 2018$ 年城乡建设用地 的基础上, 利用 ArcGIS 10.2 平台制作出覆盖阳原 县的 $100 \mathrm{~m} \times 100 \mathrm{~m}$ 格网, 将格网与城乡建设用地数 据叠加并作分区统计, 计算每个格网内的建设用地 面积, 并利用 Getis - Oder $G_{i}^{*}$ 功能分析格网统计汇 总后的建设用地空间分布数据, 探测出阳原县 $2000 、 2005 、 2010 、 2018$ 年建设用地冷热点区域, 进 而揭示乡村空间中心集聚性,具体计算公式如下:

$$
\begin{gathered}
G_{i}^{*}=\frac{\sum_{j=1}^{n} w_{i j} x_{j}-\bar{X} \sum_{j=1}^{n} w_{i j}}{S \sqrt{\frac{1}{n-1}\left[n \sum_{j=1}^{n} w_{i j}^{2}-\left(\sum_{j=1}^{n} w_{i j}\right)^{2}\right]}} \\
\bar{X}=\frac{1}{n} \sum_{j=1}^{n} x_{j}, S=\sqrt{\frac{1}{n} \sum_{j=1}^{n} x_{j}^{2}-\bar{X}^{2}}
\end{gathered}
$$

式中: $x_{j}$ 是每个统计网格的属性值; $w_{i j}$ 是 $i$ 和 $j$ 的空 间权重, 在探测中采取空间搜索半径法, 以 $100 \mathrm{~m}$ 为 相关距离构建出空间权重矩阵。

\subsection{3 乡村空间成长性探测}

乡村地域系统演化会导致乡村建设用地的空 间变化。乡村空间成长性是反映乡村建设用地成 长强度的指标, 乡村空间成长热点则是一段时期内 生产要素最活跃、土地利用结构改变最强烈、空间 格局变化最显著的地方。为了揭示乡村成长性特 征, 本文采用建设用地扩张强度反映不同时期内 乡村建设用地扩张情况, 其实质是用各网格的用 地面积对其年平均扩张速度进行标准化处理 ${ }^{[16-17]}$, 使其具有横向可比性, 具体计算如式(3)所示。在此 基础上, 利用 ArcGIS 中的 Getis - Oder $G_{i}^{*}$ 功能对 2000-2010年与 2010-2018 年阳原县建设用地扩 张强度进行冷热点分析, 其中 $G_{i}^{*}$ 的高低反映了建
设用地空间拓展强度空间集中性的强弱,进而揭示 出城乡空间扩张的空间差异性。

$$
L_{i}=\frac{R_{\mathrm{b}}-R_{\mathrm{a}}}{R_{\mathrm{a}} \times T} \times 100 \%
$$

式中: $R_{\mathrm{a}} 、 R_{\mathrm{b}}$ 分别为各网格研究初期与研究末期 乡村建设用地的数量; $T$ 是研究期时间跨度, 单位为 $\mathrm{a} ; L_{i}$ 为某一研究期内各网格内建设用地扩张强度。

\section{2 结果分析}

\section{1 城、镇、村土地利用格局变化}

如表 1 所示, 2000-2018 年阳原县城市与乡村 建设用地不断增长, 城市建设用地面积由 $9.22 \mathrm{~km}^{2}$ 增长到 $11.65 \mathrm{~km}^{2}$, 增长了 $2.43 \mathrm{~km}^{2}$, 增幅为 $26.36 \%$, 增长量主要集中在阳原县城及其周边地区(图 2); 乡 村建设用地面积由 $35.54 \mathrm{~km}^{2}$ 增长到 $58.83 \mathrm{~km}^{2}$, 增 长了 $23.29 \mathrm{~km}^{2}$, 增幅为 $65.53 \%$, 增速明显高于城市 建设用地。然而, 乡村建设用地增长呈点状分散在 河谷平原地区, 未产生明显的空间集聚。各乡镇的 建设用地扩张强度差异性较大, 西城镇、东城镇以 及化稍营镇的建设用地扩张强度高于 $5 \%$, 而辛堡 乡、大田洼乡与井儿沟乡的建设用地扩张强度不足 3\%(图 2)。在此过程中, 阳原县耕地面积由 1075.33 $\mathrm{km}^{2}$ 减少到 $1026.45 \mathrm{~km}^{2}$, 减少了 $48.88 \mathrm{~km}^{2}$, 降幅为 $4.55 \%$ 。研究数据显示, 阳原县 $100 \%$ 的城市建设用 地增长量与 $89.77 \%$ 的乡村建设用地增长量都来自 于对耕地的占用。

如表 2 所示, 2000 年以来阳原县乡村建设用地 扩张强度高于乡镇政府所在地以及县城的建设用 地扩张强度。在2000-2010年间,城、镇、村建设用 地扩张强度分别为 $2.44 \% 、 2.91 \%$ 与 $5.79 \%, 2010$ 2018 年间阳原县城、镇、村建设用地扩张强度普遍 回落, 分别为 $0.75 \% 、 1.80 \%$ 和 $1.95 \%$ 。

表 1 阳原县土地利用变化

Tab.1 Land use areas in Yangyuan County $\left(\mathrm{km}^{2}\right)$

\begin{tabular}{lrrr}
\hline \multicolumn{1}{c}{ 用地类型 } & 2000年 & 2010年 & 2018 年 \\
\hline 耕地 & 1075.33 & 1050.13 & 1026.45 \\
城市建设用地 & 9.22 & 11.08 & 11.65 \\
乡村建设用地 & 35.54 & 53.75 & 58.83 \\
林地 & 223.82 & 223.52 & 221.13 \\
草地 & 443.52 & 448.66 & 445.06 \\
水域 & 27.19 & 23.18 & 49.49 \\
未利用土地 & 30.35 & 8.09 & 2.56 \\
\hline
\end{tabular}



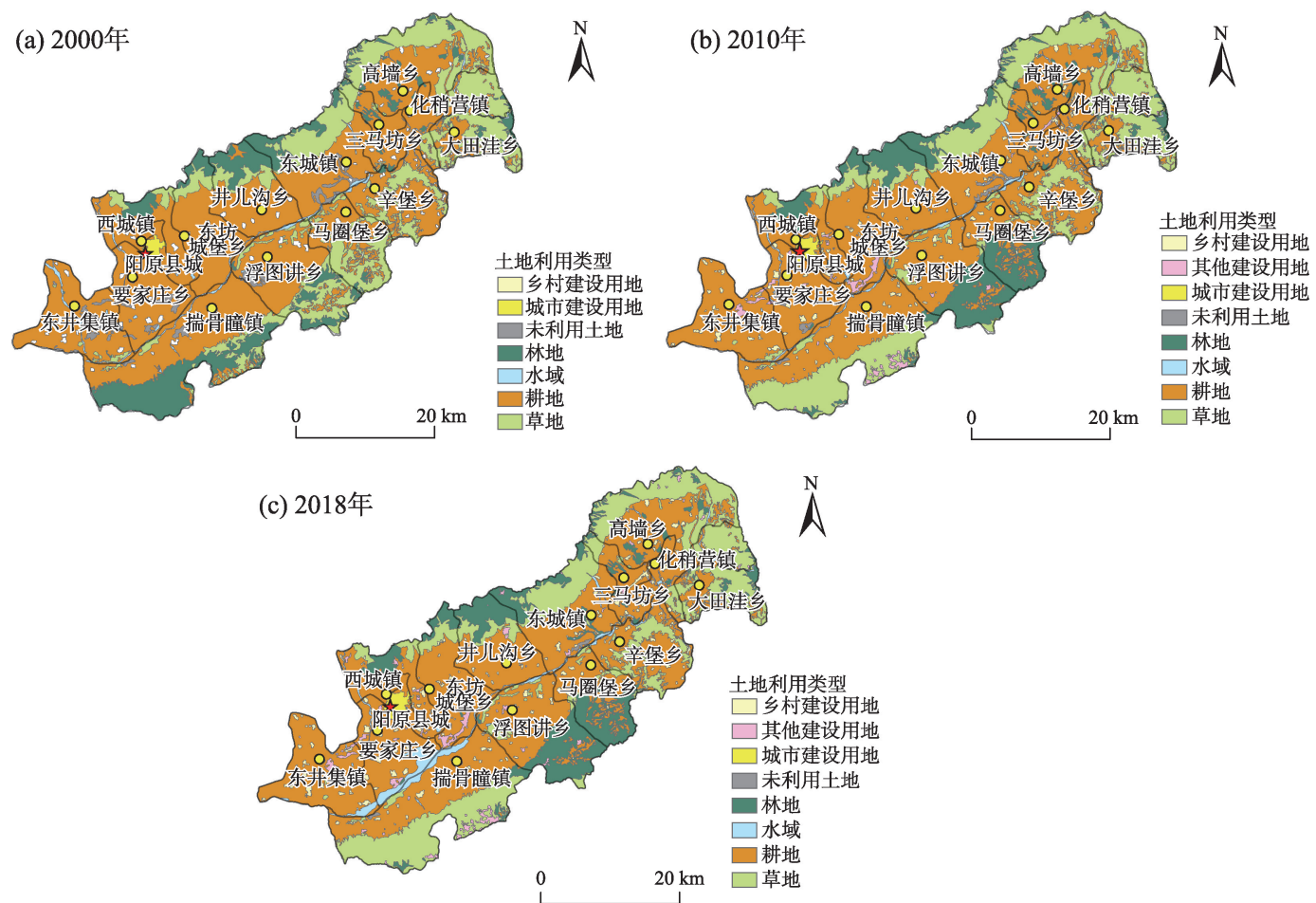

图 2 阳原县土地利用类型变化

Fig.2 Land use change of Yangyuan County

表 2 阳原县城一镇一村建设用地年均扩张强度

Tab.2 Construction land expansion intensity of county, towns, and villages in Yangyuan County

(\%)

\begin{tabular}{lcc}
\hline \multicolumn{1}{c}{ 地域类型 } & $2000-2010$ 年 & 2010 -2018 年 \\
\hline 县城 & 2.44 & 0.75 \\
乡镇政府所在地 & 2.91 & 1.80 \\
乡村 & 5.79 & 1.95 \\
\hline
\end{tabular}

\section{2 乡村中心集聚性与成长性}

如图 3 所示, 2000 年阳原县乡村建设用地的中 心集聚性最高值集中在县城周边地区, 乡镇政府所 在地、中心村的建设用地的中心集聚性水平落后于 县城周边地区,而广大偏远乡村地区的中心集聚性 水平普遍较低, 建设用地利用整体呈现单中心 “聚 核式”的空间格局特征。这一特征在 2005 年得到进 一步强化, 阳原县单中心 “聚核式” 的城乡空间体系 格局特征愈发明显。

2010 年阳原县城周边地区的乡村建设用地中 心集聚性依旧是最高的,但化稍营镇、高墙乡等东 部乡镇地区的乡村建设用地的中心集聚性明显增 强, 在东部地区逐步形成了县域发展的副中心, 改 变了单中心式的城乡空间体系。此外,在国道与高 速等交通干线周边地区的乡村建设用地中心集聚 性开始显现, 但大部分乡村依旧呈点状分散在河谷
平原地区,未产生明显的空间集聚性。2018年阳原 县东部副中心地区的乡村建设用地中心集聚性进 一步增强,并沿交通干线分布, 双核式城乡空间体 系演化特征得到巩固。

为进一步探究交通干线与行政中心对乡村建 设用地集聚规模的影响,本文利用 ArcGIS 平台的 近邻分析功能计算出各乡村到主要干道与乡镇的 距离,并利用多元线性回归模型对各村庄 2018 年建 设用地规模与到主要干道(国道、高速公路)的距离、 到乡镇中心距离等指标进行回归,发现各项指标的 $P$ 值都小于 0.1 , 呈显著负相关, 表明距离主干道、乡 镇行政中心越远,乡村建设用地规模越小。具体回 归模型如下:

$$
Y=0.2405-0.00349 X_{1}-0.00760 X_{2}\left(R^{2}=0.538\right)
$$
式中: $Y$ 是指各村庄 2018 年建设用地规模, $X_{1}$ 是指 各村庄到主要干道的距离, $X_{2}$ 是指各村庄到乡镇中 心的距离。

总体而言,阳原县城乡发展呈现“大分散、小集 聚”的空间特征。2000年以来物质、资金、人口等生 产要素不断向县城及其周边地区集聚, 导致县城周 边成为乡村建设用地集中的热点地区,中心集聚性 突出。阳原县东西狭长, 且县城位于西部, 东部地 区受到县城中心的辐射带动作用受限, 除乡镇政府 
所在地以及中心村外, 广大乡村尤其是偏远乡村地 区发展普遍缓慢。得益于高速进出口的交通优势, 化稍营镇等东部乡镇的中心集聚性日益凸显, 逐步 发展成为阳原县副中心。交通干线对于乡村建设 用地中心集聚性的空间分布产生重要影响, 宣大高 速与 109 国道的通车改变了阳原县的区位条件与交 通通达性, 加快了生产要素在城乡间的流动, 沿交通 干线周边乡村地区的生产要素集聚能力得以提升。

如图 4 所示, 2000-2018 年阳原县乡村成长性 热点分布呈显著的时空差异性。2000-2010年县 城及其周边地区是建设用地成长的主要核心区, 且
逐步向西部拓展。乡村建设用地扩张强度高值区 位于阳原县城周边的西城镇, 受到城镇化与工业化 扩张等因素的影响, 人口与产业集聚明显,建设用 地扩张强度最高。此外, 基于交通、区位的优势, 化 稍营镇、高墙乡、三马坊乡等东部乡镇城镇化与工 业化发展迅速,建设用地扩张强度较高。在 2010 2018 年间，高速公路、省道等交通干线极大提升了 阳原县对外交流的便捷性与通达性, 促使人口、资 金等生产要素向交通沿线地区聚集,从而改变了城 乡发展格局。化稍营镇至三马坊乡交通沿线地区 发展迅速, 土地利用结构发生显著变化, 成为乡村
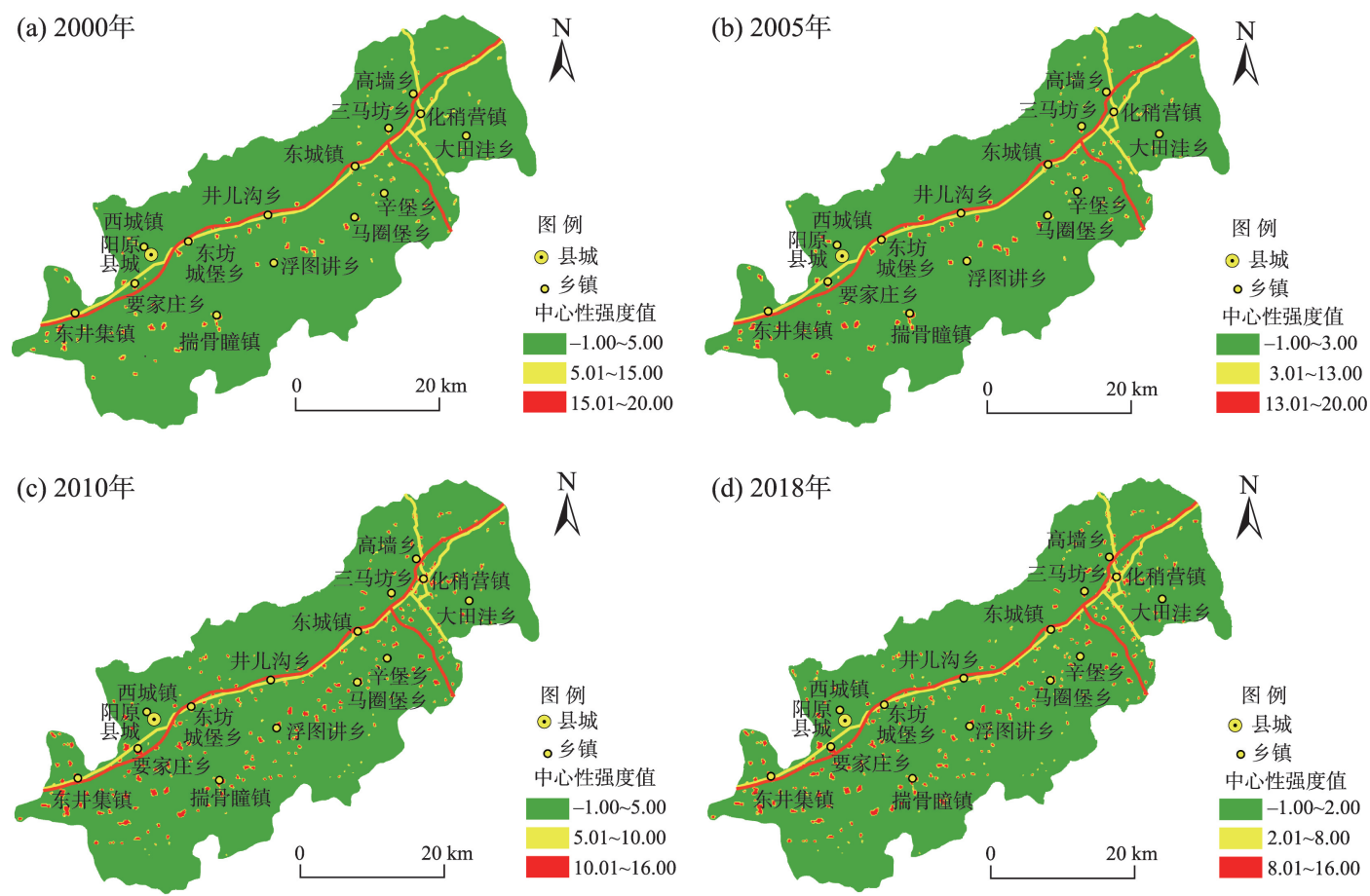

图 3 阳原县乡村建设用地中心性强度值

Fig.3 Rural construction land agglomeration degree of Yangyuan County

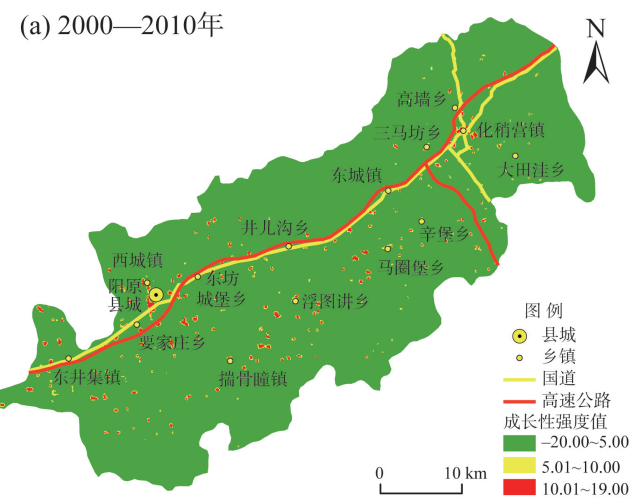

(b) 2010-2018年

图4 阳原县城乡建设用地成长性强度值

Fig.4 Urban-rural construction land growth degree of Yangyuan County 
成长的热点地区。

进一步研究发现, 距离主要交通干线较远的其 他乡镇乡村成长性普遍较低, 镇域经济实力薄弱, 对村庄的辐射带动能力受限, 除个别中心村成长性 显著外, 多数偏远乡村地区成长性不明显, 生产要 素的集聚能力较弱。

\section{3 典型乡镇人地关系变化}

为了进一步揭示阳原县乡村人地关系的演化 特征, 本文选取化稍营镇、辛堡乡 2 个典型乡镇进行 研究。化稍营镇位于阳原县东部, 距县城 $42 \mathrm{~km}$, 面 积 $94.12 \mathrm{~km}^{2}, 2018$ 年底全镇户籍人口 22832 人, 常 住人口 17507 人, 得益于阳原县政府的支持与优越 的交通条件, 镇域经济发展速度较快, 已成为阳原 县的副中心; 辛堡乡位于阳原县东南部, 距县城 32 $\mathrm{km}$, 面积 $116.4 \mathrm{~km}^{2}, 2018$ 年底辛堡乡户籍人口 12525 人, 常住人口 9328 人, 该乡镇交通便捷性较 差, 基础设施建设与经济发展水平较为落后, 为贫 困村、贫困人口集中的乡镇。

调研显示,截至 2018 年, 化稍营镇、辛堡乡的人 口流失量(户籍人口与常住人口的差值)分别为 5325 人与 3197 人, 分别占其户籍人口总数的 $23.32 \%$ 与 $25.52 \%$, 各乡村普遍处于人口流失状态(图 5)。然 而, 化稍营镇、辛堡乡的乡村建设用地却呈逐年递 增态势。2000-2018 年化稍营镇与辛堡乡的乡村 建设用地面积分别增长了 $107.63 \%$ 与 $46.10 \%$ (表 $3)$ 。乡村建设用地扩张与乡村常住人口减少同时
存在,显示出化稍营镇、辛堡乡的土地非农化并非 产业用地扩张, 也未能有效支撑乡村经济发展, 从 而形成了乡村地区“一方水土难养一方人”的境遇， 乡村人口外流与农村空心化问题突出, 进而呈现出 “人减地增”的农村空心化趋势。

\section{3 结论与讨论}

本文以河北省阳原县为例, 解析了 2000-2018 年阳原县乡村建设用地扩张的中心性与成长性规 律, 从土地利用变化视角揭示了深度贫困地区乡村 地域系统演化的时空过程及格局特征。随着乡村 人地关系的变化, 深度贫困地区的乡村中心集聚性 与成长性发生了显著变化。生产要素在城、镇、村 间不均衡集聚的特征明显, 导致县城邻近地区、乡 镇政府所在地、偏远乡村地区的中心集聚性依次降 低。受区位、交通、自然环境等因素的影响,县城邻

表3 化稍营镇与辛堡乡建设用地变化

Tab.3 Changes in construction land in Huashaoying

Town and Xinbu Town

$\left(\mathrm{km}^{2}\right)$

\begin{tabular}{ccc}
\hline 年份 & 化稍营镇 & 辛堡乡 \\
\hline 2000 & 2.36 & 3.08 \\
2005 & 2.54 & 3.26 \\
2010 & 4.57 & 4.37 \\
2018 & 4.90 & 4.50 \\
\hline
\end{tabular}

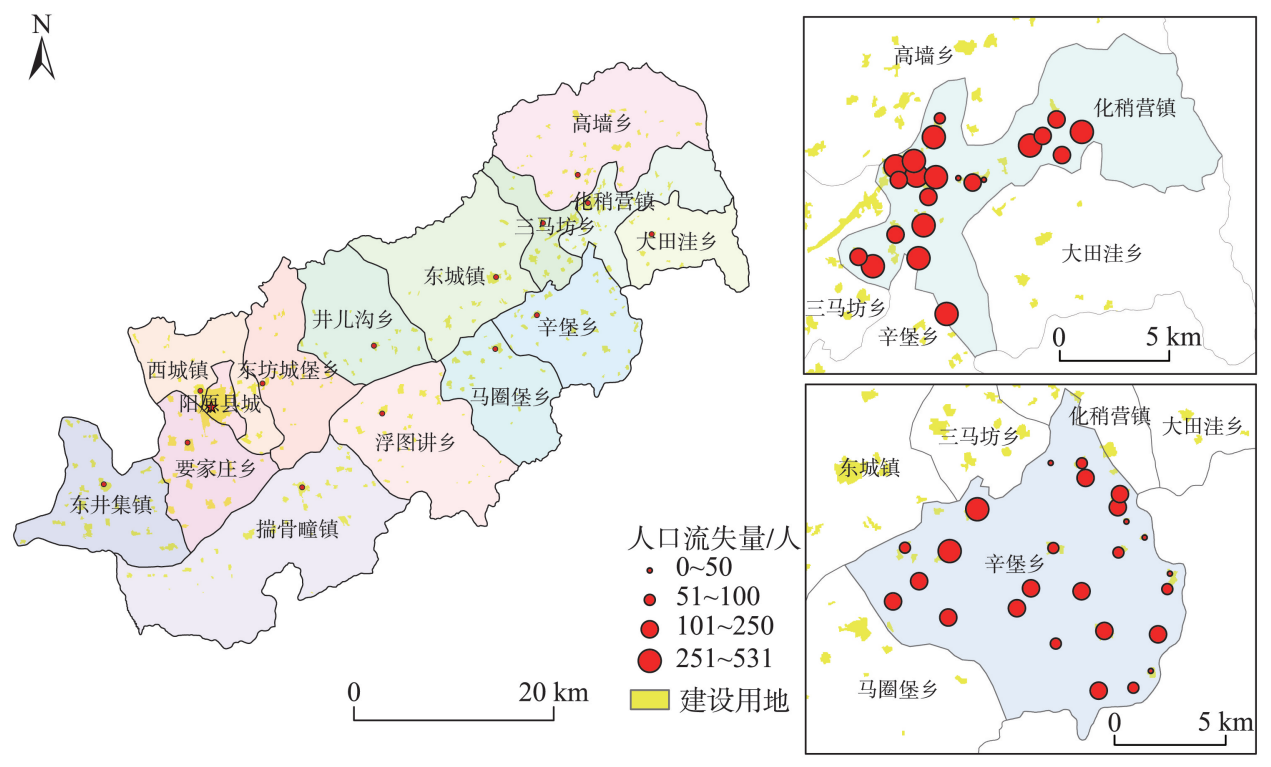

图 5 化稍营镇与辛堡乡各村庄人口流失量

Fig.5 Population loss by village in Huashaoying Town and Xinbu Town 
近地区、区位较好的乡镇以及交通干线附近地区更 易于集聚生产要素, 成为乡村成长性的高值区。然 而, 乡村建设用地的快速扩张与乡村常住人口的大 量减少并存, “人减地增”的农村空心化倾向严重, 进一步揭示了深度贫困地区乡村发展质量不高、乡 村衰退的特征。

县城是引领县域经济与社会发展的核心, 然 而, 中国深度贫困地区经济发展基础薄弱, 交通通 达性差, 县域经济整体发展水平较低, 产业缺乏竞 争力, 有效吸纳农村剩余劳动力受限, 导致县城对 乡村尤其是偏远乡村地区的辐射带动作用不强, 农 村发展缓慢、空心化蔓延的特征明显。以实施乡村 振兴战略为导向, 深度贫困地区应明确自身功能定 位、发展思路与路径, 不断提升乡村地区基础设施 水平与交通通达性, 充分挖掘乡村自身优势条件, 提高产业竞争力与吸纳就业能力, 增强城乡联系以 及县城对乡村地区的辐射带动作用。

作为增进城乡联系的纽带, 乡镇在疏解城市功 能、服务带动偏远乡村地区发展、完善城乡空间体 系等方面具有重要的作用 ${ }^{[18]}$ 。本文研究结果显示, 深度贫困地区的城乡发展呈现“大分散、小集聚”的 空间格局特征, 乡镇地区的生产要素集聚能力不 足, 制约了其对偏远乡村的辐射带动作用。基于 此, 深度贫困地区要着力发展以重点镇、中心村、新 型农村社区为载体的村镇化平台, 构建层次分明、 分工明确、功能互补的城、镇、村空间体系, 提升乡 镇对偏远乡村的辐射带动能力, 从而实现村镇化与 城市化 “双轮驱动”发展 ${ }^{[19]}$ 。

激发与提升深度贫困地区乡村发展的内生动 力对于有效应对乡村衰退至关重要。乡村人口流 失引发了农村土地空废化与社会主体弱化等问题, 降低了乡村地区的可持续发展能力。积极开展空 心村土地综合整治能够有效整合、配置土地资源, 协调乡村人地关系, 增强乡村农业生产功能 ${ }^{[4,20]}$, 实 现农村生产、生活及生态空间的重构与优化。社会 资本日益成为发展经济与解决贫困的重要因素 ${ }^{[21]}$, 应注重培育乡村社会资本, 增强民众的社会联系、 信任以及行为规范, 增进民众间、民众与企业、政府 间的了解与互信, 激发民众的主观能动性与创造 性。良好的乡村社会资本是联结乡村发展各种要 素投人的“链条”与 “粘合剂”, 有助于提高生产要素 投人产出效率, 增强乡村主体凝聚力与协作力, 进 而提升乡村发展质量与内生动力 ${ }^{[2]}$ 。

\section{参考文献(References)}

[1] 陆大道, 郭来喜. 地理学的研究核心: 人地关系地域系 统: 论吴传钧院士的地理学思想与学术贡献 [J]. 地理学 报, 1998, 53(2): 3-11. [Lu Dadao, Guo Laixi. Man earth areal system: The core of geographical study: On the geographical thoughts and academic contributions of academician Wu Chuanjun. Acta Geographica Sinica, 1998, 53 (2): 3-11. ]

[2] 刘彦随. 中国新时代城乡融合与乡村振兴 [J]. 地理学 报, 2018, 73(4): 637-650. [Liu Yansui. Research on the urban-rural integration and rural revitalization in the new era in China. Acta Geographica Sinica, 2018, 73(4): 637-650. ]

[3] 龙花楼, 屠爽爽. 乡村重构的理论认知 [J]. 地理科学进 展, 2018, 37(5): 581-590. [Long Hualou, Tu Shuangshuang. Theoretical thinking of rural restructuring. Progress in Geography, 2018, 37(5): 581-590. ]

[4] 李玉恒, 阎佳玉, 武文豪, 等. 世界乡村转型历程与可持 续发展展望 [J]. 地理科学进展, 2018, 37(5): 627-635. [Li Yuheng, Yan Jiayu, Wu Wenhao, et al. The process of rural transformation in the world and prospects of sustainable development. Progress in Geography, 2018, 37(5): 627-635. ]

[5] 刘彦随. 新时代乡村振兴地理学研究 [J]. 地理研究, 2019, 38(3): 461-466. [Liu Yansui. Research on the geography of rural revitalization in the new era. Geographical Research, 2019, 38(3): 461-466. ]

[6] Liu Y S, Li Y H. Revitalize the world's countryside [J]. Nature, 2017, 548: 275-277.

[7] 郑小玉, 刘彦随. 新时期中国 “乡村病”的科学内涵、形成 机制及调控策略 [J]. 人文地理, 2018, 33(2): 100-106. [Zheng Xiaoyu, Liu Yansui. Connotation, formation mechanism and regulation strategies of rural disease in the new epoch in China. Human Geography, 2018, 33(2): 100-106. ]

[8] 刘彦随, 周扬, 刘继来. 中国农村贫困化地域分异特征及 其精准扶贫策略 [J]. 中国科学院院刊, 2016, 31(3): 269278. [Liu Yansui, Zhou Yang, Liu Jilai. Regional differentiation characteristics of rural poverty and targeted pover alleviation strategy in China. Bulletin of Chinese Academy of Sciences, 2016, 31(3): 269-278. ]

[9] 李玉恒, 阎佳玉, 宋传圭. 乡村振兴与可持续发展: 国际 典型案例剖析及其启示 [J]. 地理研究, 2019, 38(3): 595604. [Li Yuheng, Yan Jiayu, Song Chuanyao. Rural revitalization and sustainable development: Typical case analysis and its enlightenments. Geographical Research, 2019, 38(3): 595-604. ]

[10] 刘彦随, 周扬, 李玉恒. 中国乡村地域系统与乡村振兴 
战略 [J]. 地理学报, 2019, 74(12): 2511-2528. [Liu Yansui, Zhou Yang, Li Yuheng. Rural regional system and rural revitalization strategy in China. Acta Geographica Sinica, 2019, 74(12): 2511-2528. ]

[11] Mooney H A, Duraiappah A, Larigauderie A. Evolution of natural and social science interactions in global change research programs [J]. PNAS, 2013, 110(S1): 3665-3672.

[12] 张富刚, 刘彦随. 中国区域农村发展动力机制及其发展 模式 [J]. 地理学报, 2008, 63(2): 115-122. [Zhang Fugang, Liu Yansui. Dynamic mechanism and models of regional rural development in China. Acta Geographica Sinica, 2008, 63(2): 115-122. ]

[13] 李双成, 蔡运龙. 地理尺度转换若干问题的初步探讨 [J]. 地理研究, 2005, 24(1): 11-18. [Li Shuangcheng, Cai Yunlong. Some scaling issues of geography. Geographical Research, 2005, 24(1): 11-18. ]

[14] 孟斌, 王劲峰. 地理数据尺度转换方法研究进展 [J]. 地 理学报, 2005, 60(2): 277-288. [Meng Bin, Wang Jinfeng. A review on the methodology of scaling with geodata. Acta Geographica Sinica, 2005, 60(2): 277-288. ]

[15] 刘彦随, 杨忍. 中国环渤海地区城乡发展转型格局测度 [J]. 地理学报, 2015, 70(2): 248-256. [Liu Yansui, Yang Ren. The spatial pattern measure of urban-rural development transformation in the Bohai Rim region in China. Acta Geographica Sinica, 2015, 70(2): 248-256. ]

[16] 李晓文, 方精云, 朴世龙. 上海城市用地扩展强度、模式 及其空间分异特征 [J]. 自然资源学报, 2003, 18(4): 412-422. [Li Xiaowen, Fang Jingyun, Piao Shilong. The intensity and modes of urban land use growth in Shanghai. Journal of Natural Resources, 2003, 18(4): 412-422. ]

[17] 刘浩, 张毅, 郑文升. 城市土地集约利用与区域城市化 的时空耦合协调发展评价: 以环渤海地区城市为例
[J]. 地理研究，2011，30(10): 1805- 1817. [Liu Hao, Zhang Yi, Zheng Wensheng. Evaluation on spatial-temporal development and interaction of intensive urban land use and urbanization: Case studies of cities in Bohai Rim region. Geographical Research, 2011, 30(10): 18051817. ]

[18] Li Y H, Zhang Q. Human-environment interaction in China: Evidence of land-use change in Beijing-Tianjin-Hebei Metropolitan region [J]. Human Ecology Review, 2013, 20(1): 26-35

[19] 李玉恒, 阎佳玉, 刘彦随. 基于乡村弹性的乡村振兴理 论认知与路径研究 [J]. 地理学报, 2019, 74(10): 20012010. [Li Yuheng, Yan Jiayu, Liu Yansui. The cognition and path analysis of rural revitalization theory based on rural resilience. Acta Geographica Sinica, 2019, 74(10): 2001-2010. ]

[20] 马历, 龙花楼, 屠爽爽, 等. 基于乡村多功能理论的贫困 村域演变特征与振兴路径探讨: 以海南省什寒村为例 [J]. 地理科学进展, 2019, 38(9): 1435-1446. [Ma Li, Long Hualou, Tu Shuangshuang, et al. Characteristics of change and vitalization pathways of poor villages based on multifunctional rural development theory: A case study of Zahan Village in Hainan Province. Progress in Geography, 2019, 38(9): 1435-1446. ]

[21] 孔翠翠, 刘静, 朱青, 等. 社会资本的地理学研究进展 [J]. 地理科学进展, 2016, 35(8): 1039-1048. [Kong Cuicui, Liu Jing, Zhu Qing, et al. Progress of social capital research in geography. Progress in Geography, 2016, 35 (8): 1039-1048. ]

[22] Li Y H, Westlund H, Zheng X Y, et al. Bottom-up initiatives and revival in the face of rural decline: Case studies from China and Sweden [J]. Journal of Rural Studies, 2016, 47: 506-513. 


\title{
Change of rural regional system in deep poverty areas:
}

\section{A case study of Yangyuan County, Hebei Province}

\author{
LI Yuheng ${ }^{1,2,3}$, SONG Chuanyao ${ }^{1,2,3}$, YAN Jiayu $^{1,2,3}$, HUANG Huiqian ${ }^{1,2,3}$ \\ (1. Institute of Geographic Sciences and Natural Resources Research, CAS, Beijing 100101, China; \\ 2. Key Laboratory of Regional Sustainable Development Modeling, CAS, Beijing 100101, China; \\ 3. College of Resources and Environment, University of Chinese Academy of Sciences, Beijing 100049, China)
}

\begin{abstract}
Under the influence of rapid urbanization and industrialization, the problems of "rural diseases" faced by rural areas, especially the deep poverty areas are prominent, affecting rural sustainable development. There is an urgent need to better understand the process and characteristics of rural regional system change, identify restricting factors of rural development, and propose the suitable paths of rural revitalization for promoting rural sustainable development. This study took Yangyuan County as an example, investigated rural central agglomeration and growth from the perspective of land-use change, and revealed the evolution characteristics of rural human-land relationship in deep poverty areas. The results show that: 1) With the continuous reduction of arable land, the expansion intensity of villages is higher than that of township government seats and the county seat. 2) The agglomeration degree of production factors in the county seat, towns, and villages is imbalanced, resulting in a declining central agglomeration from the areas near the county seat to township government seats, and to remote rural villages. 3) Affected by the factors of traffic, location, and natural environment, areas near the county seat, better- located townships, and areas near transportation arteries are more likely to gather production factors and become high-value areas for rural growth. 4) The problem of rural resident population outflow is serious in deep poverty areas, causing rural hollowing with a phenomenon of declining populationincreasing land. The article emphasized that the economic development level and urban-rural connection should be improved to enhance the county seat's ability to facilitate development in the countryside, and ruralization should be promoted alongside urbanization. Besides, it is necessary to implement comprehensive land consolidation in hollowed villages and cultivate rural social capital to promote endogenous rural development.
\end{abstract}

Keywords: rural decline; rural change; sustainable development; ruralization; Hebei Province 